\title{
Acute Dehydration in Nephrotic Syndrome: A Case Report
}

\section{Gianluigi Ardissino', Andrée Van Lierde², Gabriella Moroni ${ }^{3}$, Francesca Tel1, Michela Perrone, Mirco Belingheri ${ }^{3}$}

\footnotetext{
${ }^{1}$ Center for HUS Prevention, Control and Management, Fondazione IRCCS Ca' Granda, Ospedale Maggiore Policlinico, Milan, Italy ${ }^{2}$ Department of Pediatrics, University of Milan, Milan, Italy

${ }^{3}$ Unit of Nephrology and Dialysis, Fondazione IRCCS Ca' Granda, Ospedale Maggiore Policlinico, Milan, Italy

Email: ardissino@centroseu.org,francesca.tel@gmail.com, michiperrone@gmail.com,mircobelingheri@hotmail.com
}

How to cite this paper: Ardissino, G., Van Lierde, A., Moroni, G., Tel, F., Perrone, M. and Belingheri, M. (2017) Acute Dehydration in Nephrotic Syndrome: A Case Report. Open Journal of Nephrology, 7, 5660.

https://doi.org/10.4236/ojneph.2017.72007

Received: May 22, 2017

Accepted: June 20, 2017

Published: June 23, 2017

Copyright $\odot 2017$ by authors and Scientific Research Publishing Inc. This work is licensed under the Creative Commons Attribution International License (CC BY 4.0).

http://creativecommons.org/licenses/by/4.0/

\section{Open Access}

\begin{abstract}
The management of acutely dehydrated children with relapsed nephrotic syndrome (NS) can be challenging when edema and intravascular volume depletion are present simultaneously. In that condition the excess in body fluid, typically associated with NS, may be inappropriately low, with regard to albumin level, and the excess in fluid is not promptly shifted into the vascular bed because of the low plasma protein concentration. This peculiar condition exposes the child to a greater risk of acute kidney injury (AKI) particularly if albumin infusion is provided. Here in a case of dehydration in ongoing NS is described in order to highlight the danger of infusing albumin when dehydration coexists. The present case report provides a framework for discussing an unusual and preventable pathophysiological mechanism of AKI related to the inappropriate administration of albumin infusion.
\end{abstract}

\section{Keywords}

Acute Kidney Failure, Nephrotic Syndrome, Dehydration, Albumin, Hemodialysis

\section{Introduction}

The management of acutely dehydrated children with relapsed nephrotic syndrome (NS) can pose special clinical problems and may be a therapeutic challenge for the physicians involved in the early treatment decisions. Indeed, it may seem unusual that an edematous child could require rehydration, but the paradox arises from the fact that the fluid excess in the extravascular system may be inappropriately low with respect to the level of albumin. This particular condition exposes the child to a greater risk of acute kidney injury (AKI), which is oth- 
erwise a rare complication of idiopathic childhood NS [1]-[6].

The following case report describes the clinical course of a child with relapsed NS and associated dehydration, and provides a framework for discussing an unusual pathophysiological mechanism of AKI possibly related to albumin infusion.

\section{Case Report}

This 13-year-old Filipino girl with idiopathic steroid-dependent NS was admitted to our Pediatric Department because of vomiting, diarrhea, abdominal pain and oliguria. She was on steroid therapy, which had been increased two days before the hospitalization from $40 \mathrm{mg} / \mathrm{m}^{2}$ of body surface area (bsa) every other day to $60 \mathrm{mg} / \mathrm{m}^{2}$ daily because of NS relapse. On admission the clinical examination revealed puffy eyes and mild edema at the lower extremities; her weight was $38.5 \mathrm{~kg}$ (proteinuria-free baseline weight was $37 \mathrm{~kg}$ ) and her blood pressure was normal (117/79 $\mathrm{mmHg})$. Laboratory tests, performed on admission, showed an ongoing AKI with BUN of $40.7 \mathrm{mg} / \mathrm{dL}$ and $\mathrm{sCr}$ of $1.88 \mathrm{mg} / \mathrm{dL}$, serum total proteins of $37 \mathrm{~g} / \mathrm{L}, \mathrm{WBC}$ of $37,600 / \mathrm{mm}^{3}$ with high normal inflammatory indices (PCR $7 \mathrm{mg} / \mathrm{dl})$, HCT was $54 \%$ and urinary protein $(\mathrm{mg} / \mathrm{dL}) /$ urinary creatinine $(\mathrm{mg} / \mathrm{dL})$ ratio $(\mathrm{uPr} / \mathrm{uCr})$ was 14.3 .

An i.v. infusion of albumin $20 \%(300 \mathrm{ml} / 24 \mathrm{~h})$ was started immediately after admission while an infusion of saline $700 \mathrm{ml} / 24 \mathrm{hrs}$ was added only five hours later; because of vomiting the incoming oral fluid in the first 24 hrs was below $500 \mathrm{ml}$. On the second day, severe oliguria was present (urine output $260 \mathrm{ml} / 24$ $\mathrm{h}$ ) and the patient's weight had increased to $39.7 \mathrm{~kg}$. Renal function worsened (creatinine $2.78 \mathrm{mg} / \mathrm{dl}$ ), urinary protein excretion increased ( $\mathrm{uPr} / \mathrm{uCr}$ up to 42 ), and hypertension developed (156/96 $\mathrm{mmHg})$.

Albumin 20\% (50 ml/24 h) was continued, and the oral intake and i.v. infusion of fluids were utterly restricted (total intake $950 \mathrm{ml} / 24 \mathrm{~h}$ ). Dopamine 2.9 $\mathrm{mcg} / \mathrm{kg} / \mathrm{min}$, i.v. furosemide $180 \mathrm{mg}$, and spironolactone $150 \mathrm{mg}$ were added. Nevertheless, oliguria persisted and renal failure worsened $(\mathrm{sCr} 5.4 \mathrm{mg} / \mathrm{dL}$ on day 9); the girl became drowsy, and had severe headache and persistent hypertension $(168 / 105 \mathrm{mmHg})$ requiring antihypertensive treatment (amlodipine 5 $\mathrm{mg} / 24 \mathrm{~h})$.

Microscopic urine examination showed severe isomorphous microhematuria and cylindruria, with a large number of tubular cells.

A renal biopsy performed at this time did not reveal any significant glomerular or vascular abnormality, but showed severe and diffuse damage of the tubular epithelium, with vacuolization, cytoplasmic protein microinclusions (Figure 1(a)), and the precipitation of several protein casts in the tubular lumina associated with tubular necrosis in some areas (Figure 1(b)).

The patient underwent two hemodialysis sessions on days 9 and 10, which were followed by a progressive increase in urine output $(850 \mathrm{ml} / 24 \mathrm{~h}$ on day 13$)$ and improved renal function ( $\mathrm{sCr} 1.63 \mathrm{mg} / \mathrm{dl}$ on day 19). NS ( $\mathrm{uPr} / \mathrm{uCr} 25)$ with weight gain, generalized edema and ascites persisted. On day 20, i.v. pulse methylprednisolone $20 \mathrm{mg} / \mathrm{kg} /$ day was started and continued for three consecutive 


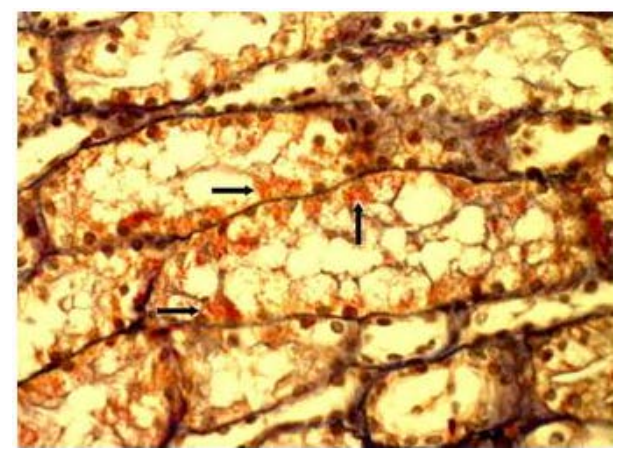

(a)

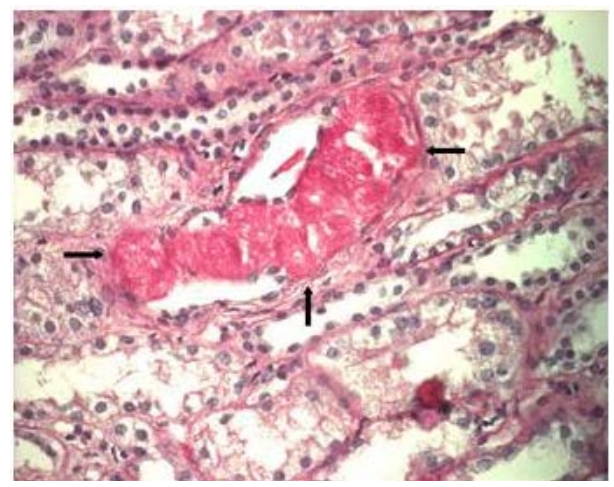

(b)

Figure 1. Dilated tubular structures and severe vacuolation of epithelial cells cytoplasm due to protein resorption (a) and micrograph showing a normal glomerulus, dilated tubules lined by little epithelium or desquamation and necrosis of tubular cells, and the precipitation of protein casts in the lumina (b).

days, followed by oral prednisone $30 \mathrm{mg} / \mathrm{m}^{2}$ bsa daily, without response; cyclophosphamide $2 \mathrm{mg} / \mathrm{kg} /$ day was therefore added on day 30 and continued for twelve weeks, at the end of which proteinuria ( $>1 \mathrm{~g} / 24$ hours) still persisted with normal renal function. The patient's urine was protein free on day 180 , only after cyclosporine (5.5 mg/kg/day) has been introduced (day 120 ).

\section{Discussion}

The management of dehydration in patients with NS must consider some particular pathophysiological aspects of the underlying condition, including the serum albumin concentration and the amount of proteinuria. In normal subjects, the increased oncotic pressure related to acute dehydration and the consequent increase in plasma protein concentrations shift water from the interstitial compartment to the vascular bed in proportion to the absolute increase of plasma protein concentration. In a child with NS, an equal loss of water leads to a smaller increase in absolute plasma protein concentration and in oncotic pressure. The result of this altered pathophysiology is a reduced shift of water into the vascular system regardless of the excess fluid in the extravascular system. This implies that the hemodynamic condition of patients with ongoing NS is more precarious, thus making them a lot more susceptible to AKI [1] [2] [7] [8].

It may seem paradoxical to consider a child with edema and $1.5 \mathrm{~kg}$ of esti- 
mated water excess (baseline weight was $37 \mathrm{~kg}$ ) as being dehydrated. However, in our opinion, this overweight was disproportionately low with respect to the relatively low protein level $(37 \mathrm{~g} / \mathrm{L})$ and the high amount of proteinuria $(\mathrm{uPr} / \mathrm{uCr}$ 14.3).

The pathophysiology of AKI in NS patients can include one or more of the following mechanisms: low renal perfusion pressure in the case of severe hypoprotidemia, acute tubular necrosis, high intratubular pressure, interstitial nephritis and interstitial edema [1] [2] [3] [4] [5] [9].

It may seem reasonable to treat a dehydrated child with severe hypoprotidemia by administering albumin to mobilize the sequestered fluids thus avoiding to further increase the already existing water excess [10] [11] [12] [13]. It must be kept in mind that administered albumin will eventually lead to a massive increase in protein loss into the tubules [3] [14] [15]. The disproportion between hypoalbuminemia (NOT in nephrotic range) and protinuria (IN nephrotic range) should be considered an indicator of a possible dehydration and discourage the clinician to approach the child with NS recurrence and mild edema by administering albumin as the first line treatment. As already reported by Koomans et al. [16], in the dehydration and antidiuresis condition, a massive infusion of albumin may induce a very high tubular protein concentration, with tubular clogging and precipitation of protein casts in the tubules. This process may also be favored if acidosis and aciduria coexist as commonly observed in dehydrated children [17].

In our case, renal histology showed severe and diffuse tubular epithelial damage, likely attributable to the generous albumin infusion, without appropriate water administration, in the first hours after the patient hospitalization.

In conclusion, we suggest using albumin infusion with caution in dehydrated patients with relapsing NS; a more rational approach is perhaps to simply administer a saline solution, followed by albumin infusion only in case of severe generalized edema, but never the other way around.

\section{References}

[1] Vande Walle, J., Mauel, R., Raes, A., et al. (2004) ARF in Children with Minimal Change Nephrotic Syndrome May Be Related to Functional Changes of Glomerular Basal Membrane. American Journal of Kidney Diseases, 43, 399-404. https://doi.org/10.1053/j.ajkd.2003.10.039

[2] Harris, R.C. and Ismail, N. (1994) Extrarenal Complications of the Nephritic Syndrome. American Journal of Kidney Diseases, 23, 477-497. https://doi.org/10.1016/S0272-6386(12)80369-6

[3] Venkataseshan, V.S., Faraggiana, T., Grishman, E., et al. (1993) Renal Failure Due to Tubular Obstruction by Large Protein Casts in Patients with Massive Proteinuria. Clinical Nephrology, 39, 321-326.

[4] Agarwal, N., Phadke, K.D., Garg, I. and Alexander, P. (2003) Acute Renal Failure in Children with Idiopathic Nephrotic Syndrome. Pediatric Nephrology, 18, 12891292. https://doi.org/10.1007/s00467-003-1259-1

[5] Rheault, M.N., Zhang, L., Selewski, D.T., et al. (2015) AKI in Children Hospitalized with Nephrotic Syndrome. Clinical Journal of the American Society of Nephrology, 
10, 2110-2118. https://doi.org/10.2215/CJN.06620615

[6] Pstrusinska, K., Zwolinska, D. and Musial, K. (2000) Acute Renal Failure in Children with Idiopathic Nephrotic Syndrome. Polski Merkuriusz Lekarski, 8, 462-464.

[7] Koomans, H.A. (2003) Pathophysiology of Oedema in Idiopathic Nephrotic Syndrome. Nephrology Dialysis Transplantation, 18, vi30-vi32. https://doi.org/10.1093/ndt/gfg1063

[8] Yaseen, A., Tresa, V., Lanewala, A.A., Hashmi, S., et al. (2017). Acute Kidney Injury in Idiopathic Nephrotic Syndrome of Childhood Is a Major Risk Factor for the Development of Chronic Kidney Disease. Renal Failure, 39, 323-327. https://doi.org/10.1080/0886022X.2016.1277743

[9] Lowestein, J., Schacht, R.G. and Baldwin, D.S. (1981) Renal Failure in Minimal Change Nephrotic Syndrome. The American Journal of Medicine, 70, 227-233. https://doi.org/10.1016/0002-9343(81)90754-3

[10] Loghman, A.M., Siegler, R.L. and Pysher, T.J. (1997) Acute Renal Failure in Idiopathic Nephrotic Syndrome. Clinical Nephrology, 47, 76-80.

[11] Sakemi, T., Uchida, M., Baba, N., et al. (1991) Renal Failure with Nephrotic Syndrome: Reversal with Large Doses of Furosemide. Nippon Jinzo Gakkai Shi, 33, 59-64.

[12] Na, K.Y., Han, J.S., Kim, Y.S., et al. (2001) Does Albumin Preinfusion Potentiate Diuretic Action of Furosemide in Patients with Nephrotic Syndrome? Journal of Korean Medical Science, 16, 448-454.

[13] Bircan, Z., Kervancioglu, M., Katar, S. and Vitrinel, A. (2001) Does Albumin and Furosemide Therapy Affect Plasma Volume in Nephrotic Children? Pediatric Nephrology, 16, 497-499. https://doi.org/10.1007/s004670100576

[14] Guglielminotti, J. and Guidet, B. (1999) Acute Renal Failure in Rhabdomyolysis. Minerva Anestesiologica, 65, 250-255.

[15] Zager, R.A. (1988) Precipitable Tissue Proteins Can Cause Experimental Acute Renal Failure. Laboratory Investigation, 59, 798-808.

[16] Koomans, H.A. (2001) Pathophysiology of Acute Renal Failure in Idiopathic Nephrotic Syndrome. Nephrology Dialysis Transplantation, 16, 221-224. https://doi.org/10.1093/ndt/16.2.221

[17] Bank, N. and Better, O.S. (1991) Acid-Base Balance and Acute Renal Failure. Mineral and Electrolyte Metabolism, 17, 116-123.

\section{Scientific Research Publishing}

\section{Submit or recommend next manuscript to SCIRP and we will provide best} service for you:

Accepting pre-submission inquiries through Email, Facebook, LinkedIn, Twitter, etc. A wide selection of journals (inclusive of 9 subjects, more than 200 journals)

Providing 24-hour high-quality service

User-friendly online submission system

Fair and swift peer-review system

Efficient typesetting and proofreading procedure

Display of the result of downloads and visits, as well as the number of cited articles

Maximum dissemination of your research work

Submit your manuscript at: http://papersubmission.scirp.org/

Or contact ojneph@scirp.org 